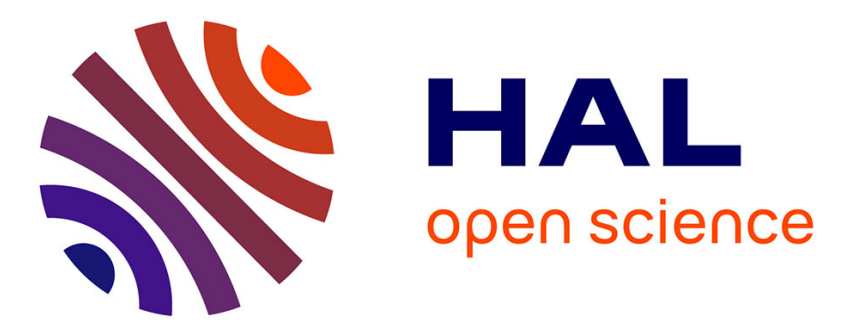

\title{
The bigger, the smaller: relationship between body size and food stores in the stingless bee Melipona flavolineata
}

Jamille Veiga, Cristiano Menezes, Giorgio Venturieri, Felipe Contrera

\section{To cite this version:}

Jamille Veiga, Cristiano Menezes, Giorgio Venturieri, Felipe Contrera. The bigger, the smaller: relationship between body size and food stores in the stingless bee Melipona flavolineata. Apidologie, 2013, 44 (3), pp.324-333. 10.1007/s13592-012-0183-4 . hal-01201301

\section{HAL Id: hal-01201301 \\ https://hal.science/hal-01201301}

Submitted on 17 Sep 2015

HAL is a multi-disciplinary open access archive for the deposit and dissemination of scientific research documents, whether they are published or not. The documents may come from teaching and research institutions in France or abroad, or from public or private research centers.
L'archive ouverte pluridisciplinaire HAL, est destinée au dépôt et à la diffusion de documents scientifiques de niveau recherche, publiés ou non, émanant des établissements d'enseignement et de recherche français ou étrangers, des laboratoires publics ou privés. 


\title{
The bigger, the smaller: relationship between body size and food stores in the stingless bee Melipona flavolineata
}

\author{
Jamille C. VeigA ${ }^{1}$, Cristiano Menezes ${ }^{2}$, Giorgio C. Venturieri ${ }^{2}$, \\ Felipe A. L. CONTRERA ${ }^{1}$

\begin{abstract}
${ }^{1}$ Laboratório de Ecologia e Zoologia de Invertebrados, Universidade Federal do Pará Instituto de Ciências Biológicas, Rua Augusto Corrêa, No 1, Campus Básico, Guamá, CEP 66075-110 Belém, PA, Brazil ${ }^{2}$ Laboratório de Botânica, Embrapa Amazônia Oriental, Travessa Dr. Enéas Pinheiro s/n, Caixa Postal 48, Belém CEP 66095-100, PA, Brazil
\end{abstract}

Received 21 May 2012 - Revised 24 October 2012 - Accepted 8 November 2012

\begin{abstract}
Worker body size is a key feature for stingless bee biology, being related with the foraging range of colonies. We correlated the intertegular span, corbicular area, head width, and interocular distance, as well as the fresh weight, from workers of Melipona flavolineata, a species from the Amazonian Region, with the stored reserves of honey and pollen. The food reserves decreased with the increase of rainfall, and there was a significant correlation between intertegular span, corbicular area, and food stores. The corbiculae was inversely correlated with food reserves, while the width of thorax was positively related. We consider the allometric variation of thorax width and corbicular area as a mechanism to adjust colonial food collection, since larger corbiculae would maximize the pollen-gathering during the rainy, dearth periods, and when the resource supply increases, the workers increase in the width of thorax, being able to explore larger areas and replenish the colonial food stores.
\end{abstract}

corbiculae / intertegular distance / food collection / foraging range / meliponine bees

\section{INTRODUCTION}

Weather is an important determining element for several activities of solitary and social bees, including the patterns of external activity (Hilário et al. 2001; Pereboom and Biesmeijer 2003; Pyke et al. 2011) and resource gathering, which is redirected to the nutrition of larvae and adults (Roulston and Goodell 2011). In stingless bees (Hymenoptera, Apidae, Meliponini, sensu Michener 2000), the influence of food stores on the sex ratio has been established: the lesser the stores, the fewer individuals produced, particularly drones (e.g., Moo-Valle et al. 2001).

Corresponding author: J.C. Veiga, jal.cveiga@gmail.com; F.A.L. Contrera, felipe@ufpa.br

Manuscript editor: Stan Schneider
Regarding drones, Pech-May et al. (2012) also found a positive relation between food stores and body size, as well as sperm quantity. Seasonal availability of food resources also seems to influence the proportion of queens among females (van Veen et al. 1999; MooValle et al. 2001; Morais et al. 2006; Ferreira Jr et al. 2012). Kerr et al. (1966) predicted that, during starvation periods, Melipona colonies would provision less food to their brood, and consequently, less queens would be produced. So far, however, there are no data on seasonal quantitative and qualitative variations in larval food of Melipona species (Hartfelder et al. 2006).

Size variation in worker caste related to environmental factors and food stores has not been extensively investigated, although body 
size is a key aspect for the colony fitness, since at least $75.5 \%$ of the size variation of workers is not attributed to phylogenetic effects but to food collection necessities (Pignata and DinizFilho 1996). Body weight has been observed to change in relation to age in Melipona quadrifasciata anthidioides Lepeletier, 1836 (Contrera et al. 2006), and Ramalho et al. (1998), in the same species, observed an inverse relationship of colony condition, overall worker size, and the size of the corbiculae. In this species, the allometric variation of body and corbiculae sizes may help to maximize pollen collection in dearth periods because, when colonies become weaker and invest in smaller workers, they individually have larger corbiculae and can thus bring back larger pollen loads.

For the Mesoamerican meliponine species Nannotrigona perilampoides Cresson, 1878, Quezada-Euán et al. (2011) showed that the quality and the quantity of the larval food offered to workers was also a relevant factor influencing worker caste size variation, with seasonal variations in food stores hypothesized to correlate with body size. In regard to seasonality, Roubik (1982) found a relationship between it and worker longevity in Melipona favosa Fabricius, 1798, and Melipona fulva Lepeletier, 1836; in a dearth period (the rainy season in his study), when the food stores decreased, worker longevity increased, and in times of food abundance, the longevity decreased, perhaps influenced by the increased foraging effort they exerted (see Schmid-Hempel and Wolf 1988).

Since in stingless bees, like in other bee groups, body size is correlated with foraging range (Roubik and Aluja 1983; van Niewstadt and Iraheta 1996; Araújo et al. 2004; Greenleaf et al. 2007) and with intra-specific variations (Ramalho et al. 1998; Kuhn-Neto et al. 2009), the aim of this study was to understand how the food stores are influenced by rainfall (seasonal food dearth) and its relation with body size variation of workers in a Melipona species from the Amazonian Region, where the distinct dry and rainy seasons influence the food stores of the colonies and several life-history traits of this Neotropical bee group (Roubik 1989).

\section{MATERIALS AND METHODS}

The subject species of this study was Melipona flavolineata Friese, 1900, which occurs in the states of Maranhão, Pará, Tocantins, and Ceará (Camargo and Pedro 2008), the first three States part of the Brazilian Amazon. All the experiments were performed in the meliponary of Embrapa Amazônia Oriental $\left(1^{\circ} 26^{\prime} 11.52^{\prime \prime} \mathrm{S}, 48^{\circ} 26^{\prime} 35.50^{\prime \prime} \mathrm{W}\right)$, in Belém, Pará State, Brazil. The climate of the region is type $A f$ (according to the Köppen Geiger classification), which is characterized by dry seasons with a precipitation no less than $60 \mathrm{~mm}$ on the dry months of the year and high temperatures (Peel et al. 2007).

The subject colonies were kept in hives designed for their breeding (Venturieri 2004), and during all this period, they did not receive extra food and did not have their food stores disturbed or augmented. Thus, they survived only with the resources they could collect in the area (secondary forests patches and several agricultural crops). The experiments were executed from September 2010 to June 2011, and consisted of three procedures, described below.

\subsection{Worker morphometry and weight}

Monthly, and starting in October 2010, we removed newly emerged workers from three colonies of M. flavolineata (colony 2, the strongest; colony 3, medium; and 5, the weakest, considering population size, flight activity, and food stores) to obtain their fresh weight (using a digital balance O-HAUS Marte MP4 V2.5 Class 2; $d=0.001 \mathrm{~g}$ ). We started the experiments with five colonies, but, in the second month, two of them lost their queens, thus being removed from our analysis. After this procedure, the workers were killed, and their interocular distance, intertegular distance, and head width were obtained in a stereomicroscope Zeiss Discovery V-20 EMS-2. The area (in square millimeters) of the rightcorbiculae was also measured; photographs of the corbiculae were taken with a Moticam 2500 5.0Mpixel USB 2.0 camera mounted on a Motic MLC-150C digital stereomicroscope and then measured by using the software Motic Image Plus 2.0.

The maximum number of workers removed from each colony per month was ten, in order to avoid 
weakening of the subject colonies. We manually removed workers, by selecting combs with workers ready to emerge and placing them in heated hives. When the workers were ready to emerge (verified through the observation of movement inside the cell), the cell lids were opened with the aid of tweezers, and they were immediately weighed before they could feed and thus change their weight.

\subsection{Colonies' resource-gathering and food stores}

For all studied colonies during the experimental period, beginning in September 2010, we counted once a week, during $5 \mathrm{~min} / \mathrm{h} /$ colony, how many foragers returned with nectar and pollen (Nates-Parra and Rodríguez 2011), according the protocol of Oliveira (1973; followed by, e.g., Pierrot and Schlindwein 2003; Hilário and Imperatriz-Fonseca 2009). The observations were made from $0600 \mathrm{~h}$ until $1200 \mathrm{~h}$, the period when more than $90 \%$ of foraging trips are made (e.g., Hilário et al. 2000, 2001). The goal of this procedure was to estimate how the gathering of nectar and pollen varied across the experimental period. We also measured how the food reserves of the colonies varied, by the counting of the honey and pollen food pots with contents that were present in the hives.

\subsection{Analysis}

In stingless bees, brood cells are massprovisioned, thus completed before oviposition (Sakagami 1982; Roubik 1989). After egg-laying, the cell is closed and the individuals develop (34 to 38 days from egg to adult in workers of $M$. quadrifasciata; Kerr 1950; no data for M. flavolineata). We therefore related the body size of the newly emerged workers from the different colonies $(N=249$; three colonies; Table I) with the food stores of the previous month.

Excluding the corbiculae, the other body size variables (fresh weight, interocular distance, head width, and intertegular distance) were correlated (Pearson's correlation test $\geq 0.20, P<0.05$ ), thus we chose the intertegular distance and the corbicular area to run the tests. The choice of intertegular distance is due to its relevance with foraging range and the corbiculae with the pollen-carrying capacity (see "Introduction"). Before choosing the tests to compare these measures with the food stores of the colony, we standardized the measures of corbicular area and intertegular distance, because they had different units (cubic millimeters and millimeters, respectively). Thus, the comparisons were made by using the relative size of corbicular area and intertegular distance. The standardization was performed by subtracting each measure by the mean and dividing it by its standard deviation.

Since the standardized intertegular distance did not have a normal distribution (Shapiro's Wilk $W$, 0.94, $P<0.0001)$ nor homogeneous variances (Levene's test, $F_{(2,246)}=3.96, P=0.02$ ) and the standardized corbicular area followed the parametric assumptions (normal data, Shapiro's Wilk W, 0.99, $P=0.098$; homogeneous variances, Levene's test, $\left.F_{(2,246)}=2.94, P=0.06\right)$, we chose non-parametric tests when considering the intertegular distance and parametric tests when considering the corbicular area.

To verify if the intertegular distance and corbicular area (standardized values) varied according the seasons (rainy or dry), we used a Student's $t$ test

Table I. Mass and measurements (means \pm SE) of 249 newly emerged workers of M. flavolineata, collected between October 2010 and June 2011 in the study site.

\begin{tabular}{lllllll}
\hline Colony & Fresh weight $(\mathrm{g})$ & ID $(\mathrm{mm})$ & HW $(\mathrm{mm})$ & IT $(\mathrm{mm})$ & CA $\left(\mathrm{mm}^{2}\right)$ & $N$ \\
\hline 2 & $0.066 \pm 0.001$ & $2.865 \pm 0.006$ & $4.508 \pm 0.007$ & $3.236 \pm 0.013$ & $2.226 \pm 0.017$ & 90 \\
3 & $0.061 \pm 0.001$ & $2.814 \pm 0.007$ & $4.446 \pm 0.010$ & $3.148 \pm 0.013$ & $2.260 \pm 0.018$ & 75 \\
5 & $0.058 \pm 0.001$ & $2.802 \pm 0.006$ & $4.462 \pm 0.009$ & $3.132 \pm 0.009$ & $2.471 \pm 0.023$ & 84 \\
\hline
\end{tabular}

Data given as averages

$I D$ interocular distance, $H W$ head width, $I T$ intertegular distance, $C A$ right corbiculae area 
(for the corbicular area) and the Mann-Whitney's $U$ test for the intertegular distance (Zar 1999). To verify the influence of the food stores (total stores, since the honey and pollen pots were correlated, Spearman's $R=0.20, P<0.05)$ on the body size variation in $M$. flavolineata, we used a simple regression (for the corbicular area) and a Spearman's correlation test for the intertegular distance.

We also performed a simple regression between the standardized intertegular distance and corbicular area to values to verify if there was any allometric variation between them (by verifying the slope of the regression equation). We also performed a Spearman correlation test $(R)$ between monthly precipitation and pollen and nectar gathering and food reserves. For all tests, we used a significance level of $5 \%$ (Zar 1999).
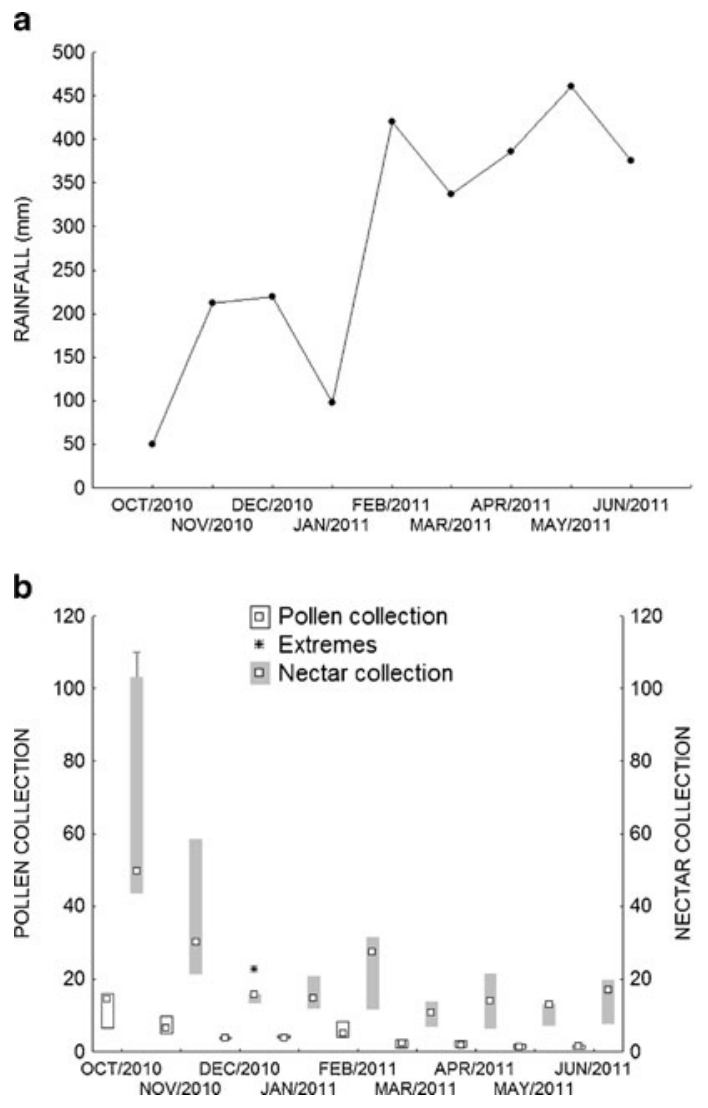

\section{RESULTS}

\subsection{Rainfall and food collection and reserves}

There was a clear dry and wet season during the study period (dry season: September 2010January 2011; rainy season: February-June 2011, Figure 1a), and the precipitation rates were inversely correlated with the nectar (Spearman $R=-0.47, P<0.05$; Figure $1 \mathrm{~b}$ ) and pollen collection (Spearman $R=-0.57, P<0.05$; Figure 1b). With respect to the food stores (Figure 1c), the total reserves of food decreased with the increment of rainfall (Spearman $R=$ $-0.39, P<0.05$; honey reserves, $R=-0.40, P<$ 0.05 ; pollen reserves, $R=-0.03, P=\mathrm{ns}$ ).

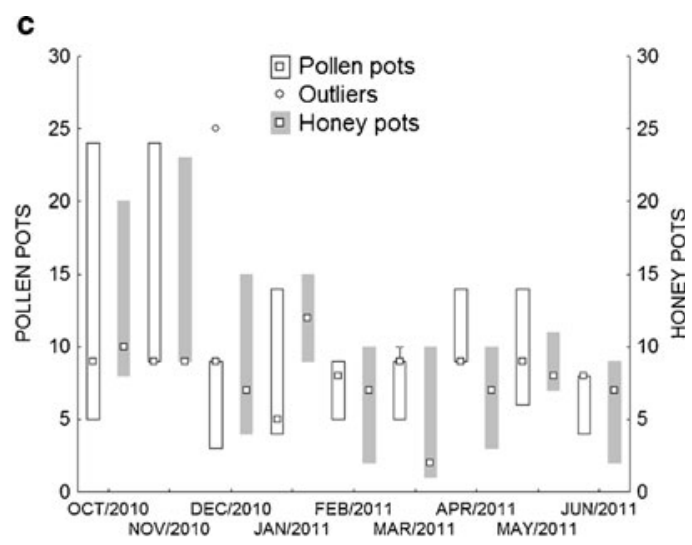

Figure 1. Levels of rainfall in the study area (a), stores of honey and pollen (b), and the collection of nectar and pollen (c) of three colonies of M. flavolineata. 


\subsection{Food reserves, rainfall, and body size}

The size of the corbiculae and intertegular distance followed an allometric and inverse pattern $(N=249$, corbicular area $=-0.0068$ $0.1257 \times$ intertegular distance, $P=0.049$ ); the bigger the corbiculae, the smaller the intertegular distance. The colonies differed in the mean size of the corbiculae and intertegular distance (Tukey's HSD; $P<0.05$ ); the colony 2, the strongest, had the biggest (considering all the study period, not the seasonal variation) intertegular distance and smaller corbiculae whereas the colony 5 had the smaller intertegular distance and the bigger corbular area (Table I).

There was an influence of the total stores of pollen and honey as well as colonial effects on the overall body size variation (standardized values) in $M$. flavolineata. The intertegular distance of colonies 2 and 3 significantly increased $(R \approx 0.50)$ with the increment of food stores (Table II) while the intertegular distance of colony 5 did not suffer a significant influence $(P=0.06)$ from them. In an opposite way, the corbicular area of colonies 2 and 3 were not influenced by the food stores, but the corbicular area of colony 5 significantly decreased $(\beta=$ $-0.45)$ with the increment of the food stores (Table III).

The intertegular distance of all colonies decreased in the rainy season (February-June 2011; $U=4,633.5, Z=5.30, P<0.00001)$, whereas the size of the corbiculae followed the inverse pattern (All colonies, $t_{(\mathrm{df}=247)}=-4.23, P=$ $0.00003)$. Only colony 2 did not experience a significant increase of the corbiculae in the rainy season $\left(t_{(\mathrm{df}=88)}=-1.78, P=0.08\right.$; Figure $\left.2 \mathrm{a}-\mathrm{d}\right)$.

\section{DISCUSSION}

As central-place foragers (Elliott 1988), stingless bee's workers must return to their perennial nests after each foraging trip, to unload and process the gathered resources. In meliponine bees, there is a recognized relationship between their body size, especially their intertegular span, and the foraging range of individuals and colonies (Roubik and Aluja 1983; van Niewstadt and Iraheta 1996; Araújo et al. 2004; Kuhn-Neto et al. 2009). One might expect that colonies would always invest in larger individuals, with a potential to explore the largest foraging area possible. However, the relation between worker body size and the fitness/survival of the colony involves several factors, such as the climate, the amount of the food stores, and the competition with other colonies.

A key determinant of activity and resource gathering in bees is the climate, because it can affect the individuals (e.g., direct mortality caused by a pouring rain) and the colony, when the resources they gather diminish in dearth periods. Stingless bees from tropical areas, especially from the Amazonian Region, experience distinct dry and rainy seasons, where in the rainy season the floral resources become scarcer and the colonies rely on their food stores in order to survive (Roubik 1982, 1989). In our study, we found a significant correlation between the intertegular span, the corbiculae size of workers, and the stores of honey and pollen of M. flavolineata. However, the link between worker size and pollen gathering is complex, because the overall body size of bees and the

Table II. Effects (Spearman's $R$ ) of the total stores of pollen and honey on the intertegular distance of newly emerged workers from three colonies of $M$. flavolineata.

\begin{tabular}{|c|c|c|c|c|c|c|c|c|}
\hline & \multicolumn{2}{|c|}{ Colony 2} & \multicolumn{2}{|c|}{ Colony 3} & \multicolumn{2}{|c|}{ Colony 5} & \multicolumn{2}{|c|}{ All colonies } \\
\hline & $R$ & $P$ value & $R$ & $p$ value & $R$ & $p$ value & $R$ & $p$ value \\
\hline $\begin{array}{l}\text { Intertegular distance versus } \\
\text { total stores }\end{array}$ & 0.49 & $<0.01$ & 0.45 & $<0.01$ & 0.16 & 0.10 & 0.40 & 0.001 \\
\hline
\end{tabular}


size of their corbiculae are inversely correlated (as Ramalho et al. 1998, found in M. quadrifasciata). In the rainy season, when food stores are decreased $(R=-0.40)$, all colonies produced smaller individuals concerning the width of thorax, and two colonies produced individuals with larger corbiculae, except the strongest colony (colony 2), in which the increase of corbiculae was non-significant $(P=0.08)$.

Ramalho et al. (1998) showed that the smaller individuals can carry proportionally more pollen than the larger ones, thus the colonies can save food stores and still can keep reasonable pollen loading capabilities. On the other hand, these smaller individuals have a smaller foraging range, since the intertegular distance is closely related to flight distance because the flight muscles are inserted in this area (Greenleaf et al. 2007).

When the colony food stores increased, the pattern was inverted; the colony invested in bigger overall individuals (intertegular distance), which are able to explore a larger area, to maximize the collection of pollen and nectar, but can carry less pollen per unit of weight (Ramalho et al. 1998). These compensatory mechanisms of allometric variations and its implications are not yet fully understood in stingless bees, but they clearly can confer adaptive benefits to the colonies (as shown by Grüter et al. 2012). As Ramalho (1998) found, we also acknowledged a colonial effect in our data: the weaker the colony, the smaller the intertegular distance and the greater the corbicular area, although the described seasonal variation of proportions between intertegular distance and corbiculae we described still applies (Figure 2a-d).

This pattern can, for instance, be valid in a context when all colonies in a particular area experienced the shrinking on their food stores during the rainy season and must, in the richer, dry season, increase their foraging to replenish the food stores. Since, in stingless bees there is a fierce competition by food sources, with some groups (e.g., Trigona spp.) tending to monopolize richer food sources (Nieh et al. 2005), it seems a good strategy that in the dry season the 
a

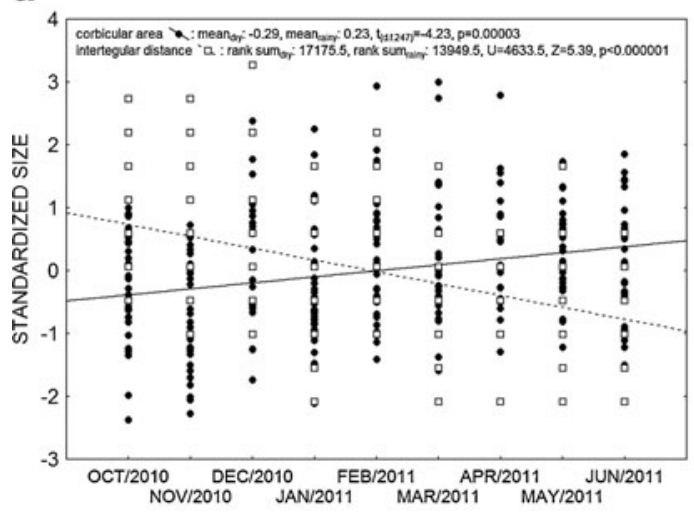

b

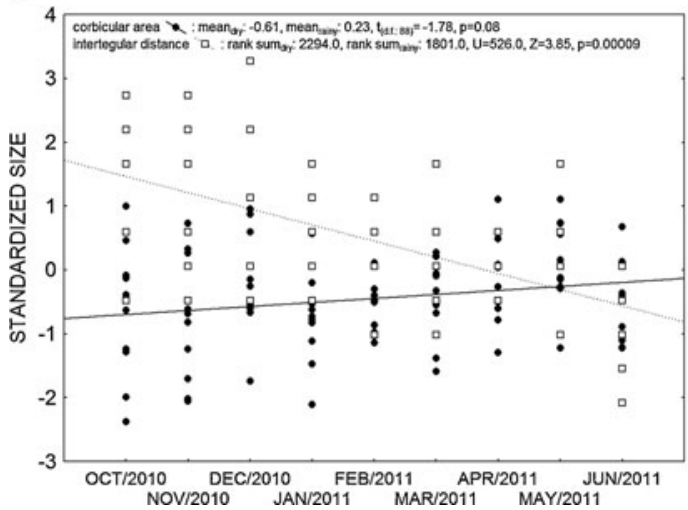

C

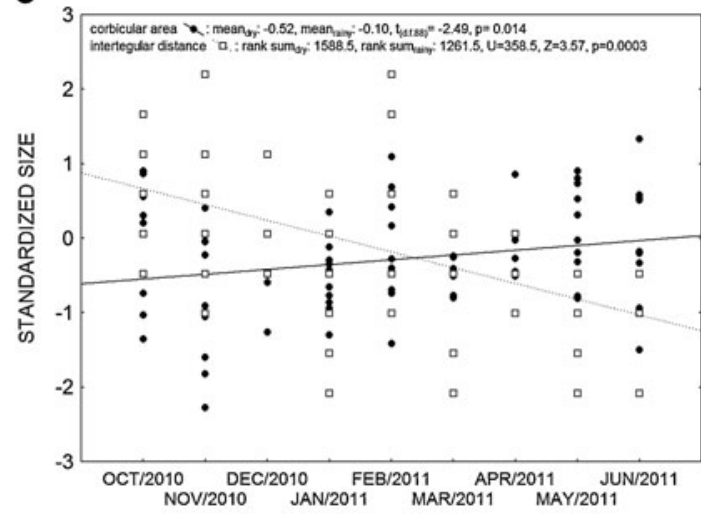

d

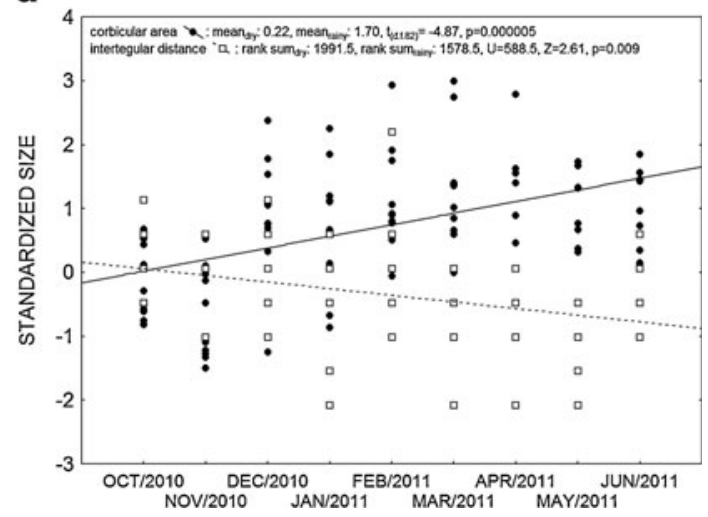

Figure 2. Relationships between the standardized measures of corbicular areas, intertegular distances of $M$. flavolineata workers, for all colonies (a) and colonies 2 (b), 3 (c), and 5 (d) during the study period.

colonies (specially Melipona spp., which normally evades direct conflicts on flowers; Nieh et al. 2005) invest in larger individuals that can explore larger areas, thus allowing them to explore areas not used by other competitors. Surely, to confirm this hypothesis, experiments at the community level, estimating the body size variation of several species and the quantity of resources they collect, as well as estimating their foraging range, must be performed.

Other taxa respond differently to these climatic constraints in food availability. In the bumblebee Bombus impatiens Cresson 1863, there is a great difference in body mass and size between the smaller and larger workers within the colony, a difference difficult to explain based only upon foraging. Following the general trends observed for bees, smaller bumble bee foragers were poorer foragers than large foragers (Jandt and Dornhaus 2009). However, small bumble bee workers are more resistant to starvation than bigger workers (Couvillon and Dornhaus 2010), thus contributing to their survival on harsh climates with limited resources (for B. impatiens, the Alpine areas where they inhabit). Similarly, in Apis mellifera Linnaeus, 1758, reserves of fatty acid in the worker's body are associated with the onset of foraging: foragers were significantly leaner and had less lipid reserves than nurse bees (Tóth and Robinson 2005). Furthermore, depletion of food was found to stimulate workers to become foragers (Tóth et al. 2005).

Although the amount of food the colonies have stored and food availability in the envi- 
ronment affects worker body size (Roulston and Goodell 2011), there are other factors that might influence the worker size that we did not evaluate in this study, such as the quality and quantity of the larval food. In N. perilampoides, the larval food is highly and positively correlated with worker size (Quezada-Euán et al. 2011). In their work, the authors also acknowledged the possibility of seasonal variations in worker size. Our results, although in a different bee genus, showed that a good amount of the worker size variation for most of the colonies can be explained by the quantity of food reserves from the previous month (since it takes at least 30 days to the eggs develop into an adult bee). However, other factors may also play a role. Recently, Grüter et al. (2012) found that guards of Tetragonisca angustula Latreille 1811, are significantly heavier and have larger legs than foragers, and guard bees can more efficiently fight the robber bee Lestrimellita limao Smith, 1863. If in M. flavolineata, or in other Melipona, there is alloethism, as found in T. angustula, this may account for a significant percentage of the worker's body size variation, although it still remains to be tested.

Another relevant point to be studied is the consumption of food stores. It is unclear how stingless bee colonies consume their honey and pollen reserves (Roubik 1982). For example, does the queen, in the rainy season, consume the pollen collected and stored in the richer dry season, or does the queen reduces her egglaying rate to save the stored pollen? A reduced or absent egg-laying was already described in the stingless bee Plebeia remota Holmberg, 1903, a species from subtropical areas which experience cold winters and enter in reproductive diapause (Alves et al. 2009). In this case, workers also have their longevity largely increased, in order to compensate for the absence of new individuals hatching (van Benthem et al. 1995). According our data, the pollen stores were not directly altered by the rainfall, which seems to support the idea of reduced egg-laying in the rainy period, but since we did not measure the egg-laying in our study, it also still remains to be tested.
Thus, for a complete comprehension of the regulation of body size variation in the stingless bees from tropical areas, it is necessary to analyze the influence of resources on body size, foraging range of individuals and colonies, longevity, as well as to understand how colonies store and consume their food reserves. Only with the understanding of all these life-history traits can a complete picture of the regulation of stingless bee populations be achieved.

\section{ACKNOWLEDGMENTS}

We would like to thank James C. Nieh (University of California San Diego) for critical reading of the manuscript and linguistic advice, three anonymous referees for the valuable suggestions that improved our manuscript, Selvino Neckel de Oliveira Universidade Federal de Santa Catarina for statistical advice, João Athaydes and Antônio Lola, for cordially making available the rainfall data generated by the Weather Station of Climurb Project (IG/UFPA/ $\mathrm{CNPq}$ ), and the Fundação de Amparo à Pesquisa do Estado do Pará (FAPESPA), through the PIBIC program, for funding the first author.

Plus gros, plus petit: relation entre la taille du corps et les réserves alimentaires chez l'abeille sans aiguillon Melipona flavolineata

Corbicules / distance entre tegulae / récolte de nourriture / zone d'approvisionnement / Meliponini / Apoidea

E größer umso kleiner: Beziehung zwischen Körpergröße und Einlagerung von Vorräten bei der stachellosen Biene Melipona flavolineata.

Corbiculae / Tegulaeabstand / Sammeln / Sammelradius / Meliponinae

\section{REFERENCES}

Alves, D.A., Imperatriz-Fonseca, V.L., Santos-Filho, P. (2009) Production of workers, queens and males in Plebeia remota colonies (Hymenoptera, Apidae, Meliponini), a stingless bee with reproductive diapause. Gen. Mol. Res. 8, 672-683 
Araújo, E.D., Costa, M., Chaud-Netto, J., Fowler, H.G. (2004) Body size and flight distance in stingless bees (Hymenoptera: Meliponini): inference of flight range and possible ecological implications. Braz. J. Biol. 64, 563-568

Camargo, J.M.F., Pedro, S.R.M. (2008). Meliponini Lepeletier, 1836, in Moure, J.S., Urban, D., Melo, G.A.R. (Orgs), Catalogue of bees (Hymenoptera, Apoidea) in the neotropical region-online version, available at http://www.moure.cria.org.br/catalogue, accessed May/04/2012

Contrera, F.A.L., Imperatriz-Fonseca, V.L., Koedam, D. (2006) Age-dependent mass variation in the stingless bee Melipona quadrifasciata (Apidae, Meliponini). Braz. J. Morphol. Sci. 23, 321-324

Couvillon, M.J., Dornhaus, A. (2010) Small worker bumble bees (Bombus impatiens) are hardier against starvation than their larger sisters. Insectes Soc. 57, 193-197

Elliott, P.F. (1988) Foraging behavior of a central-place forager: field tests of theoretical predictions. Am. Nat. 131, 159-174

Ferreira Jr., N.T., Blochtein, B., Serrão, J.E. (2012). Seasonal production and spatial distribution of Melipona bicolor schencki (Apidae; Meliponini) castes in brood combs in southern Brazil. Apidologie, doi:10.1007/s13592-012-0169-2 (in press)

Greenleaf, S.S., Williams, N.M., Winfree, R., Kremen, C. (2007) Bee foraging ranges and their relationship to body size. Oecologia 153, 589-596

Grüter, C., Menezes, C., Imperatriz-Fonseca, V.L., Ratnieks, F.L.W. (2012) A morphologically specialized soldier caste improves colony defense in a neotropical eusocial bee. P. Natl. Acad. Sci. USA 109, 1182-1186

Hartfelder, K., Makert, G.R., Judice, C.C., Pereira, G.A.G., Santana, W.C., Dallacqua, R., Bitondi, M.M.G. (2006) Physiological and genetic mechanisms underlying caste development, reproduction and division of labor in stingless bees. Apidologie 37, 144-163

Hilário, S.D., Imperatriz-Fonseca, V.L. (2009) Pollen foraging in colonies of Melipona bicolor (Apidae, Meliponini): effects of season, colony size and queen number. Gen. Mol. Res. 8, 664-671

Hilário, S.D., Imperatriz-Fonseca, V.L., Kleinert, A.M.P. (2001) Responses to climatic factors by foragers of Plebeia pugnax Moure (In Litt.) (Apidae, Meliponinae). Rev. Bras. Biol. 61, 191-196

Hilário, S.D., Imperatriz-Fonseca, V., Kleinert, A.M.P. (2000) Flight activity and colony strength in the stingless bee Melipona bicolor bicolor (Apidae, Meliponinae). Rev. Bras. Biol. 60, 299-306

Jandt, J.M., Dornhaus, A. (2009) Spatial organization and division of labour in the bumblebee Bombus impatiens. Anim. Behav. 77, 641-651
Kerr, W.E. (1950) Genetic determination of castes in the genus Melipona. Genetics 35, 143-152

Kerr, W.E., Stort, A.C., Montenegro, M.J. (1966) Importância de alguns fatores ambientais na determinação das castas no gênero Melipona. An. Acad. Bras. Ciênc. 38, 149-168

Kuhn-Neto, B., Contrera, F.A.L., Castro, M.S., Nieh, J.C. (2009) Long distance foraging and recruitment by a stingless bee, Melipona mandacaia. Apidologie 40, 472-480

Michener, C.D. (2007) The Bees of the World. Johns Hopkins University Press, Baltimore

Moo-Valle, H., Quezada-Euán, J.J.G., Wenseleers, T. (2001) The effect of food reserves on the production of sexual offspring in the stingless bee Melipona beecheii (Apidae, Meliponini). Insectes Soc. 48, 398-403

Morais, M.M., Nascimento, F.S., Pereira, R.A., Bego, L.R. (2006) Colony internal conditions related to caste production in Melipona compressipes fasciculata (Apidae, Meliponini). Insectes Soc. 53, 265268

Nates-Parra, G., Rodríguez, C.Á. (2011) Forrajeo en colonias de Melipona eburnea (Hymenoptera: Apidae) en el piedemonte llanero (Meta, Colombia). Rev. Col. Entomol. 37, 121-127

Nieh, J.C., Kruizinga, K., Barreto, L.S., Contrera, F.A.L., Imperatriz-Fonseca, V.L. (2005) Effect of group size on the aggression strategy of an extirpating stingless bee, Trigona spinipes. Insectes Soc. 52, $1-8$

Oliveira, M.A.C. (1973) Um método para a avaliação das atividades de vôo em Plebeia saiqui (Friese) (Hymenopyera, Meliponinae). Bolm. Zool. Biol. 30, 625-631

Pech-May, F.G., Medina-Medina, L., May-Itzá, W.J., Paxton, R.J., Quezada-Euán, J.J.G. (2012) Colony pollen reserves affect body size, sperm production and sexual development in males of the stingless bee Melipona beecheii. Insectes Soc. 59, 417-424

Peel, M.C., Finlayson, B.L., McMahon, T.A. (2007) Updated world map of the Köppen-Geiger climate classification. Hydr. Earth Syst. Sci. 4, 439473

Pereboom, J.J.M., Biesmeijer, J.C. (2003) Thermal constraints for stingless bee foragers: the importance of body size and coloration. J. Exp. Biol. 137, 42-50

Pierrot, L.M., Schlindwein, C. (2003) Variation in daily flight activity and foraging patterns in colonies of uruçu - Melipona scutellaris Latreille (Apidae, Meliponini). Rev. Bras. Zool. 20, 565-571

Pignata, M.I.B., Diniz-Filho, J.A.F. (1996) Phylogenetic autocorrelation and evolutionary constraints in worker body size of some neotropical stingless bees (Hymenoptera: Apidae). Heredity 76, 222-228 
Pyke, G.H., Inouye, D.W., Thomson, J.D. (2011) Activity and abundance of bumble bees near Crested Butte, Colorado: diel, seasonal, and elevation effects. Ecol. Entomol. 36, 511-521

Quezada-Euán, J.J.G., López-Velasco, A., Pérez-Balam, J., Moo-Valle, H., Velazquez-Madrazo, A., Paxton, R.J. (2011) Body size differs in workers produced across time and is associated with variation in the quantity and composition of larval food in Nannotrigona perilampoides (Hymenoptera, Meliponini). Insectes Soc. 58, 3138

Ramalho, M., Imperatriz-Fonseca, V.L., Giannini, T.C. (1998) Within-colony size variation of foragers and pollen load capacity in the stingless bee Melipona quadrifasciata anthidioides Lepeletier (Apidae, Hymenoptera). Apidologie 29, 221-228

Roubik, D.W. (1982) Seasonality in colony food storage, brood production and adult survivorship: studies of Melipona in tropical forest (Hymenoptera: Apidae). J. Kansas Entomol. Soc. 55, 789-800

Roubik, D.W. (1989) Ecology and natural history of tropical bees. Cambridge University Press, New York

Roubik, D.W., Aluja, M. (1983) Flight ranges of Melipona and Trigona in tropical forest. J. Kansas Entomol. Soc. 56, 217-222

Roulston, T.H., Goodell, K. (2011) The role of resources and risks in regulating wild bee populations. Annu. Rev. Entomol. 56, 293-312
Sakagami, S.F. (1982) Stingless bees. In: Hermann, H.R. (ed.) Social insects, vol. III, pp. 361-423. Academic Press, New York

Schmid-Hempel, P., Wolf, T. (1988) Foraging effort and life span of workers in a social insect. J. Anim. Ecol. 57, 509-521

Tóth, A.L., Robinson, G.E. (2005) Worker nutrition and division of labour in honeybees. Anim. Behav. 69, 4641-4649

Tóth, A.L., Kantarovich, S., Meisel, A.F., Robinson, G.E. (2005) Nutritional status influences socially regulated foraging ontogeny in honey bees. J. Exp. Biol. 208, 4641-4649

van Benthem, F.D.J., Imperatriz-Fonseca, V.L., Velthuis, H.H.W. (1995) Biology of the stingless bee Plebeia remota (Holmberg): observations and evolutionary implications. Insectes Soc. 42, 71-87

van Niewstadt, M.G.L., Iraheta, C.E.R. (1996) Relation between size and foraging range in stingless bees (Apidae, Meliponinae). Apidologie 27, 219-228

van Veen, J.W., Sommeijer, M.J., Arce, H. (1999) Colony reproduction in stingless bees, Ph.D.-Thesis, Utrecht Univ. In: Van Veen, J.W. (ed.) The role of colony development and resource availability in the regulation of queen production in Melipona beecheii, pp. 80-87. Litografia Imprenta Lil, S.A. San José

Venturieri, G.C. (2004) Meliponicultura: Criação de abelhas indígenas sem ferrão. Comun. Técn. Embrapa Amaz. Or. 118, 1-4

Zar, J.H. (1999) Biostatistical analysis. Prentice Hall, New Jersey 